\title{
Effects of Moringa Oleifera Seeds Aqueous Extract on Type-II Diabetic Nephropathy in Adult Male Albino Rat
}

\author{
NAGEH M. GABR, M.D. and AL-BAYUOMI A. FOUDA, M.D. \\ The Department of Medical Physiology, Faculty of Medicine, Al-Azhar University, Cairo, Egypt
}

\begin{abstract}
Background: Because of the potential antioxidant, antiinflammatory, and immune-modulating properties of Moringa oleifera,there is an increased interest in its potential capacity in the prevention and control of diabetes mellitus and lipids peroxidation.
\end{abstract}

Aim of Study: Evaluating the potential antidiabetic efficacy and protective activities of aqueous extract of Moringa oleifera seeds in alloxan-induced diabetic nephropathy.

Material and Methods: This experimental study wasstarted in September and ended at November, 2020. It wasperformed at Medical Physiology Department, Al-Azhar Faculty of Medicine, Cairo. Fifty adult male albino rats of a local strain were distributed randomly into 5 equal groups: Normal control group, control group received aqueous extract of Moringa seeds $(500 \mathrm{ml} / \mathrm{kg}$ body weight orally for 10 weeks), diabetic control group received a single dose of alloxan $(140 \mathrm{mg} / \mathrm{kg}$ body weight intraperitoneally), diabetic group received aqueous extract of Moringa seeds $(500 \mathrm{ml} / \mathrm{kg}$ body weight orally 10 weeks), and diabetic group received Moringa seeds aqueous extract before and after induction of diabetes in the same pervious doses.

Results: Alloxan-induced diabetes mellitus was associated with significant higher levels of serum glucose, glycosylated hemoglobin (HbAlc), and lowered level of insulin as compared to the control normal group. It was also associated with histopathological changes of renal tissues and impaired renal function in the form of significant elevations of serum $\mathrm{K}+$ $\mathrm{Na}^{+}$, creatinine, urea and uric acid levels as compared to the control normal group. Also, there were significant disturbance of lipid peroxidation represented by MDA Level and significant decrease in SOD level as compared to the control normal group. Moringa oleifera seeds aqueous extract showed significant lower levels of serum glucose, $\mathrm{HbA} 1 \mathrm{c}$ and elevated level of insulin as compared with the diabetic rats. It was also associated with histological regeneration of damaged renal tissues and restoration of renal function in the form of significant decrease of serum $\mathrm{K}+\mathrm{Na}^{+}$, creatinine, urea and uric acid levels as compared to the diabetic group. Also, there were significant amelioration of lipid peroxidation represented by significant decrease of MDA level, and significant increase

Correspondence to: Dr. Nageh M. Gabr, The Department of Medical Physiology, Faculty of Medicine,

Al-Azhar University, Cairo, Egypt of SOD level as compared to the control normal group. These results were prominent in pretreated group with Moringa seeds aqueous extract.

Conclusion: Moringa oleifera improved glycemic and lipidemic disturbances as well as have potent protective and regenerative effects for the kidney.

Key Words: Moringa oleifera-Alloxan-Diabetes mellitus - Nephropathy.

\section{Introduction}

DIABETES is a major public health problem. It is a clinical syndrome characterized by inappropriate hyperglycemia caused by a relative or absolute deficiency of insulin or by a resistance to the action of insulin at the cellular level [1]. A chronic increase in serum glucose levels can lead to macro- and micro-vascular complications, such as heart disease, hypertriglyceridemia, nephropathy, neuropathy, and retinopathy [2]

Diabetic nephropathy is a serious complication of diabetes mellitus. It is the most common cause of end stage renal failure [3].

Medicinal plants constitute an important source of potential therapeutic agents for diabetes mellitus [4]. Moringa oleifera (also known as drumstick) is a multi-purpose plant, owing to its ability to grow in both humid and hot dry lands [5]. It is rich in bioactive compounds as glycosides, antioxidants, vitamins $\mathrm{A}$ and $\mathrm{C}$, beta-carotene, iron, potassium, mineralsandother nutrients [6].

Dietary intake of antioxidants can inhibit or delay the oxidation of susceptible cellular substrates so prevent oxidative stress. Therefore, it is important to enrich our diet with antioxidants to protect against many chronic diseases [7].

The present work aimed to detect the possible effects of aqueous extract of Moringa oleifera on 
experimentally alloxan-induced type-II diabetic nephropathy in adult male albino rat.

\section{Material and Methods}

Plant material and preparation of extract:The fresh pods of Moringa oleifera were harvested from National Institute for Research farm in Cairo, and its identity was confirmed by expert taxonomist, Department of Pharmacognosy, Al-Azhar University, Cairo. Before crushing the Moringa oleifera seeds, the wings and brown coats were removed from each seed as well as any kernel that showed any signs of damage. Seeds were passed through a mesh sieve, and the powdered seed was used for the subsequent extractions. Aqueous extract was prepared by soaking exactly $100 \mathrm{~g}$ of the powdered Moringa oleifera in $250 \mathrm{ml}$ distilled water at room temperature for 72 hours and filtered using Whatman filter paper No.1. The bulk filtrate obtained was reduced in rotavapor at $40^{\circ} \mathrm{C}$ [8], and administered orally using oral cannula to rats $500 \mathrm{mg} / \mathrm{kg}$ body weight (at 9.00-10.00 AM each day) for 10 weeks [9]. The treatments were initiated on the fifth day after alloxan exposure.

The doses of Moringa oleifera powder seeds tested revealed no adverse effects in experimental animals, including possible alterations such as food intake, unusual body growth, reduced activity, diarrhea, bleeding or death [10]

Isoflurine (Nile Pharmaceutical-Egypt) was used for anesthesia.

Alloxan (Nile Pharmaceutical-Egypt) was dissolved in $0.9 \% \mathrm{NaCl}$ and injected intraperitoneally at a dose of $140 \mathrm{mg} / \mathrm{kg}$ body weight after overnight fasting.

Animals: This experimental study wasstarted in September and ended at November, 2020. It was performed at Medical Physiology Department, AlAzhar Faculty of Medicine, Cairo. A total number of seventy adult male albino rats of a local strain weighing between 80 and 120 grams (average weight was $100 \mathrm{~g}$ ) were used for this study. The animals were housed under similar standard environmental conditions in suitable cages $(40 \times 32 \times$ $40 \mathrm{~cm}$ for every 5 rats) with wide meshed raised floors to prevent coprophagia. The rats were kept ten days on ad libitum food and tap water at room temperature and natural light/dark cycle for acclimation. Animals were distributed randomly and equally into 5 groups:

Group I (Control Group) was provided standard animal pellet and water.
Group II (Moringa seeds aqueous extract-treated group): Rats received Moringa seeds aqueous extract $(500 \mathrm{ml} / \mathrm{kg}$ body weight per rat) for 10 weeks orally [10]

Group III (Diabetic control group): Rats were subjected to induction of diabetes by a single intraperitoneal injection of alloxan $(140 \mathrm{mg} / \mathrm{kg}$ body weight per rat) in normal saline, and fed on normal standard rat chow diet [11].

Group IV (Diabetic-Moringa seed aqueous extract-treated group): Diabetic rats were treated with Moringa seeds aqueous extract $(500 \mathrm{ml} /$ body weight per rat) for 10 weeks orally.

Group V (Diabetic-Moringa seed extractpretreated group): Rats were treated with Moringa seeds aqueous extract before and after induction of diabetes in the same pervious dose.

Induction of experimental diabetes: Alloxan was slowly injected intraperitoneally in a dose of $140 \mathrm{mg} / \mathrm{kg} \mathrm{BW}$. Just before alloxan injection, $2 \mathrm{ml}$ of glucose $(5 \%)$ were given orally to prevent the initial hypoglycemic effect of alloxan [11]

The development of hyperglycemia in rats was confirmed by fasting serum glucose estimation after 2 days of alloxan injection using Accu-Chek glucometer (Roche, Germany). Animals with fasting blood glucose $\geq 200 \mathrm{mg} / \mathrm{dL}$ were considered hyperglycemic and were included in the study [12] The serum glucose level was measured.

Rats with blood glucose over $400 \mathrm{mg} / \mathrm{dl}$ were treated with 2-3 units of mixtard 30 insulin every other day in order to avoid development of ketoacidosis and coma. This dose of insulin did not correct hyperglycemia. Insulin treatment was discontinued 3 days prior to sample collection [13]

Blood sampling: Blood was collected $(4 \mathrm{ml}$ of blood each) from the retro-orbital plexus using heparinized capillary tube $(0.75-1.0 \mathrm{~mm}$ internal diameter) inserted in the medial canthus. To obtain serum, the blood was collected into a dry clean graduated glass centrifuge tube. It was rapidly set to centrifuge at 3000 r.p.m. for 15 minutes. About half of the supernatant serum was sucked out into Eppendorf tubes and stored frozen at $-20^{\circ} \mathrm{C}$ [14]

Biochemical estimation in renal homogenate: The isolated kidney tissue was cut into small pieces and washed with phosphate-buffered saline and then grinded in a homogenization buffer (Roche, Germany). The lysates were homogenized on ice using a Polytron homogenizer. The solution was sonicated in an ice bath to prevent overheating for 15 seconds followed by 5 -minute centrifugation 
at $12000 \mathrm{rpm}$ and $4{ }^{\circ} \mathrm{C}$. The resultant supernatant was used for measurement of antioxidant enzyme (SOD) and renal malondialdehyde (MDA) which were measured as thiobarbituric acid reactive substances (TBARS) by a colorimetric technique [15]

Histopathological studies: At the end of the 10th week, kidney was excised for histopathological studies. Specimens from the tissues were taken immediately and stained with Hematoxylin and Eosin ( $\mathrm{H}$ and $\mathrm{E})$ and examined microscopically according to William [16]

Statistical analysis: The data were detected by Mann-Whitney $U$ test and reported as mean \pm SD. SPSS software version 25 was used for the statistical analysis to perform ANOVA followed by post hoc-test. $p<0.05$ was considered to a statistically significant.

\section{Results}

The mean \pm standard deviation of serum glucose was $98.3 \pm 5.9,95.3 \pm 8.47,382.2 \pm 20.9,296.9 \pm 16.4$ and $290.4 \pm 9.58 \mathrm{mg} / \mathrm{dl}$ in groups I, II, III, IV and V respectively. Group II showed insignificant changes in respect to the group I (control group). Diabetes induced by alloxan resulted in a significant elevation in the levels of fasting serum glucose (FSG) in group III (diabetic group) in respect to control group I, while the treatment with Moringa seeds aqueous extract reduced the elevated fasting serum glucose in groups IV and V in respect to untreated alloxan-induced diabetic group, but still significantly higher than that of groups I and II. Also, there was no significant difference in fasting blood glucose levels between group IV and group V. Moringa seeds aqueous extract has no significant influence on plasma glucose level of normal rats. Also, these results were of prominent changes in pretreatment with Moringa seeds aqueous extract (Table 1).

The mean \pm standard deviation of serum insulin was $5.02 \pm 1.1,5.1 \pm 1.03,2.55 \pm 0.4,3.6 \pm 0.87$ and $3.03 \pm 0.7 \mathrm{mg} / \mathrm{dl}$ in groups I, II, III, IV and V respectively. Group II showed insignificant changes in respect to the control group I. Diabetes induced by alloxan resulted in a significantly decrease in the levels of serum insulin in group III (diabetic group) in respect to control group I, while the treatment with Moringa seeds aqueous extract reduced the elevated insulin in groups IV and V in respect to untreated alloxan-induced diabetic group, but still significantly higher than that of groups I and II. Also, there was no significant difference in serum insulin levels between group IV and group V (Table 1).
Moringa seeds aqueous extract has no significant influence on serum insulin level of normal rats. These results were of prominent changes in pretreatment with Moringa seeds aqueous extract (Table 1).

The mean \pm standard deviation of $\mathrm{HbA} 1 \mathrm{c}$ was $3.06 \pm 0.24,3.15 \pm 0.26,5.56 \pm 0.47,4.12 \pm 0.41$ and $4.68 \pm 0.47 \mathrm{mg} / \mathrm{dl}$ in groups I, II, III, IV and V respectively. Group II showed insignificant changes in respect to the control group I. Diabetes induced by alloxan resulted in a significant elevation in the levels of HbA1c level in group III (diabetic group) in respect to control group I, while the treatment with Moringa seeds aqueous extract reduced the elevated $\mathrm{HbA} 1 \mathrm{c}$ in groups IV and $\mathrm{V}$ in respect to untreated alloxan-induced diabetic group, but still significantly higher than that of groups I and II. Also, there was no significant difference in $\mathrm{HbA} 1 \mathrm{c}$ levels between group IV and group V (Table 1).

It was noted that Moringa seeds aqueous extract has no significant influence on $\mathrm{HbA} 1 \mathrm{c}$ level of normal rats. These results were of prominent changes in pretreatment with Moringa seeds aqueous extract (Table 1).

The mean \pm standard deviation of serum $\mathrm{K}+$ was $4.79 \pm 0.21,4.48 \pm 0.33,5.9 \pm 0.35,4.69 \pm 0.23$ and $4.36 \pm 0.17 \mathrm{mg} / \mathrm{dl}$ in groups I, II, III, IV and V respectively. Group II showed insignificant changes in respect to the control group I. Diabetes induced by alloxan resulted in a significant elevation in the levels of serum $\mathrm{K}+$ in group III (diabetic group) in respect to control group I. while the treatment with Moringa seeds aqueous extract reduced the elevated serum $\mathrm{K}+$ in groups IV and V respectively in respect to untreated alloxan-induced diabetic group, but still significantly higher than that of groups I and II. Also, there was no significant difference in $\mathrm{K}+$ level between group IV and group $\mathrm{V}$ (Table 2).

Moringa seeds aqueous extract has no significant influence on serum $\mathrm{K}+$ level of normal rats. These results were of prominent changes in pretreatment with Moringa seeds aqueous extract (group V) (Table 2).

The mean \pm standard deviation of serum $\mathrm{Na}^{+}$ was $135.9 \pm 4.07,138.5 \pm 3.2,159.8 \pm 4.74,144.05 \pm$ 4.23 and $140.4 \pm 2.46 \mathrm{mg} / \mathrm{dl}$ in groups I, II, III, IV and $\mathrm{V}$ respectively. Group II showed insignificant changes in respect to the control group I. Diabetes induced by alloxan resulted in a significant elevation in the levels of serum $\mathrm{Na}^{+}$in group III (diabetic group) in respect to group I (control group), while the treatment with Moringa seeds aqueous extract 
reduced the elevated serum $\mathrm{Na}^{+}$in groups IV and $\mathrm{V}$ in respect to untreated alloxan-induced diabetic group, but still significantly higher than that of groups I and II. Also, there was no significant difference in $\mathrm{Na}^{+}$level between group IV and group V. It was noted that Moringa seeds aqueous extract has no significant influence on serum $\mathrm{Na}^{+}$ level of normal rats. These results were of prominent changes in pretreatment with Moringa seeds aqueous extract (Table 2).

The mean \pm standard deviation of serum creatinine was $0.94 \pm 0.08,0.99 \pm 0.18,1.98 \pm 0.24,1.33 \pm$ 0.42 and $1.25 \pm 0.24 \mathrm{mg} / \mathrm{dl}$ in groups I, II, III, IV and $\mathrm{V}$ respectively. Group II showed insignificant changes in respect to the control group I. Diabetes induced by alloxan resulted in a significant elevation in the levels of serum creatinine in group III (diabetic group) in respect to control group I, while the treatment with Moringa seeds aqueous extract reduced the elevated serum creatinine in groups IV and V in respect to untreated alloxan-induced diabetic group, but still significantly higher than that of groups I and II. Also, there was no significant difference in serum creatinine level between group IV and group V. Moringa seeds aqueous extract has no significant influence on serum creatinine level of normal rats. These results were of prominent changes in pretreatment with Moringa seeds aqueous extract (Table 2).

The mean \pm standard deviation of blood urea nitrogen was $8.38 \pm 2.40,8.53 \pm 2.3,44.48 \pm 2.2,20.48$ \pm 3.1 and $17.48 \pm 1.1 \mathrm{mg} / \mathrm{dl}$ in groups I, II, III, IV and $\mathrm{V}$ respectively. Group II showed insignificant changes in respect to the group I (control group). Diabetes induced by alloxan resulted in a significant elevation in the levels of blood urea nitrogen in group III (diabetic group) in respect to control group I. While the treatment with Moringa seeds aqueous extract reduced the elevated blood urea nitrogen in groups IV and $\mathrm{V}$ respectively in respect to untreated alloxan-induced diabetic group, it still significantly higher than that of groups I and II. There was no significant difference in blood urea nitrogen level between group IV and group V. It was noted that Moringa seeds aqueous extract has no significant influence on blood urea nitrogen level of normal rats. Also, these results were prominent changes in pretreatment with Moringa seeds aqueous extract (Table 2).

The mean \pm standard deviation of serum uric acid was $12.05 \pm 3.75,11.05 \pm 2.75,22.90 \pm 3.10$, $17.20 \pm 4.11$ and $13.30 \pm 3.01 \mathrm{mg} / \mathrm{dl}$ in groups I, II, III, IV and V respectively. Group II showed insignificant changes in respect to the group I (control group). Diabetes induced by alloxan resulted in a significant elevation in the levels of serum uric acid in group III (diabetic group) in respect to control group I, while the treatment with Moringa seeds aqueous extract reduced the elevated serum uric acid in groups IV and V in respect to untreated alloxan-induced diabetic group, it still significantly higher than that of groups I and II. Also, there was no significant difference in serum uric acid level between group IV and group V. It was noted that Moringa seeds aqueous extract has no significant influence on serum uric acid level of normal rats. These results were of prominent changes in pretreatment with Moringa seeds aqueous extract (Table 2).

The mean \pm standard deviation of MDA was $64.09 \pm 6.43,59.05 \pm 4.33,87.00 \pm 5.22,59.06 \pm 1.23$ and $62.22 \pm 1.44 \mathrm{mg} / \mathrm{dl}$ in groups I, II, III, IV and V respectively. Group II showed insignificant changes in respect to the group I (control group). Diabetes induced by alloxan resulted in an elevation in the levels of MDA in group III (diabetic group) in respect to control group I, while the treatment with Moringa seeds aqueous extract reduced the MDA in groups IV and $\mathrm{V}$ respectively in respect to untreated alloxan-induced diabetic group, but still significantly higher than that of groups I and II. Also, there was no significant difference in MDA level between group IV and group V. Moringa seeds aqueous extract has no significant influence on MDA levels of normal rats. These results were of prominent changes in pretreatment with Moringa seeds aqueous extract (Table 3 ).

The mean \pm standard deviation of SOD was $350.34 \pm 8.14,360.14 \pm 5.32,150.54 \pm 5.13,267.11$ \pm 2.10 and $253.09 \pm 7.16 \mathrm{mg} / \mathrm{dl}$ in groups I, II, III, IV and V respectively. Group II showed insignificant changes in respect to the control group I. Diabetes induced by alloxan resulted in a significant decrease in the levels of SOD in group III (diabetic group) in respect to control group I, while the treatment with Moringa seeds aqueous extract elevated the SOD levels in groups IV and V in respect to untreated alloxan-induced diabetic group, but still significantly higher than that of groups I and II. Also, there was no significant difference in SOD level between group IV and group V. It was noted that Moringa seeds aqueous extract has no significant influence on SOD level of normal rats. Also, these results were prominent changes in pretreatment with Moringa seeds aqueous extract (Table 3).

Histopathological examination of the renal tissues in groups I and II showed a normal renal 
Table (1): Effects of Moringa oleifera seeds aqueous extract on serum glucose, insulin and HbA1c levels in different groups (Mean $\pm \mathrm{SD})$.

\begin{tabular}{|c|c|c|c|c|c|}
\hline $\begin{array}{l}\text { Groups } \\
\text { Parameters }\end{array}$ & $\begin{array}{l}\text { Control } \\
\text { normal } \\
\text { (Group I) }\end{array}$ & $\begin{array}{l}\text { Moringa seeds aqueous } \\
\text { extract-treated group } \\
\text { (Group II) }\end{array}$ & $\begin{array}{l}\text { Diabetic } \\
\text { group } \\
\text { (Group III) }\end{array}$ & $\begin{array}{l}\text { Diabetic-Moringa seeds } \\
\text { aqueous extract } \\
\text { treated group } \\
\text { (Group IV) }\end{array}$ & $\begin{array}{c}\text { Diabetic -pretreated with } \\
\text { Moringa seeds aqueous } \\
\text { extract-treated group } \\
\text { (Group V) }\end{array}$ \\
\hline & $98.3 \pm 5.9$ & $95.3 \pm 8.47$ & $382.2 \pm 20.9$ & $296.9 \pm 16.4$ & $290.4 \pm 9.58$ \\
\hline $\begin{array}{l}\text { Fasting serum } \\
\text { glucose }(\mathrm{mg} / \mathrm{dl})\end{array}$ & & $p>0.05 *$ & $\begin{array}{l}p<0.05^{*} \\
p<0.05 \AA\end{array}$ & $\begin{array}{l}p<0.05 * \\
p>0.05 \neq \\
p>0.05 \Omega\end{array}$ & $\begin{array}{l}p<0.05^{*} \\
p>0.05 \Phi \\
p<0.05 @\end{array}$ \\
\hline & $5.02 \pm 1.1$ & $5.5 \pm 1.03$ & $2.55 \pm 0.4$ & $3.6 \pm 0.87$ & $3.03 \pm 0.7$ \\
\hline Insulin (ng/ml) & & $p>0.05 *$ & $\begin{array}{l}p<0.05^{*} \\
p<0.05 \AA\end{array}$ & $\begin{array}{l}p<0.05 * \\
p>0.05 \neq \\
p>0.05 \Omega\end{array}$ & $\begin{array}{l}p<0.05 * \\
p>0.05 \rrbracket \\
p<0.05 @\end{array}$ \\
\hline & $3.06 \pm 0.24$ & $3.15 \pm 0.26$ & $5.56 \pm 0.47$ & $4.12 \pm 0.41$ & $4.68 \pm 0.47$ \\
\hline HbA1c level & & $p>0.05 *$ & $\begin{array}{l}p<0.05^{*} \\
p<0.05 \circledast\end{array}$ & $\begin{array}{l}p<0.05 * \\
p>0.05 \neq \\
p>0.05 \Omega\end{array}$ & $\begin{array}{l}p<0.05^{*} \\
p>0.05 \rrbracket \\
p<0.05 @\end{array}$ \\
\hline
\end{tabular}

$\mathrm{N}:$ Number of rats in each group $=10$.

@: Groups V were compared to group III.

* : All groups were compared to control group I.
$\Omega$ : Groups IV was compared to group III.
(B): Groups III was compared to group II.
II : Groups V was compared to group IV

Table (2): Effects of Moringa oleifera seeds aqueous extract on serum $\mathrm{K}^{+}, \mathrm{Na}^{+}$, creatinine, urea and uric acid levels in different groups (Mean $\pm \mathrm{SD})$.

\begin{tabular}{|c|c|c|c|c|c|}
\hline Groups & $\begin{array}{l}\text { Control } \\
\text { normal } \\
\text { (Group I) }\end{array}$ & $\begin{array}{l}\text { Moringa seeds aqueous } \\
\text { extract-treated group } \\
\text { (Group II) }\end{array}$ & $\begin{array}{l}\text { Diabetic } \\
\text { group } \\
\text { (Group III) }\end{array}$ & $\begin{array}{l}\text { Diabetic-Moringa seeds } \\
\text { aqueous extract } \\
\text { treated group } \\
\text { (Group IV) }\end{array}$ & $\begin{array}{c}\text { Diabetic -pretreated with } \\
\text { Moringa seeds aqueous } \\
\text { extract-treated group } \\
\text { (Group V) }\end{array}$ \\
\hline \multirow{3}{*}{$\begin{array}{l}\text { Serum K} \mathrm{K}^{+} \\
(\mathrm{mmol} / \mathrm{L})\end{array}$} & $4.79 \pm 0.21$ & $4.48 \pm 0.33$ & $5.9 \pm 0.35$ & $4.69 \pm 0.23$ & $4.36 \pm 0.17$ \\
\hline & & $p>0.05 *$ & $\begin{array}{l}p<0.05^{*} \\
p<0.05 \circledast\end{array}$ & $\begin{array}{l}p<0.05 * \\
p>0.05 \neq \\
p>0.05 \Omega\end{array}$ & $\begin{array}{l}p<0.05 * \\
p>0.05 \Phi \\
p<0.05 @\end{array}$ \\
\hline & $135.9 \pm 4.07$ & $138.5 \pm 3.2$ & $159.8 \pm 4.74$ & $144.05 \pm 4.23$ & $140.4 \pm 2.46^{*}$ \\
\hline $\begin{array}{l}\text { Serum Na } \\
(\mathrm{mmol} / \mathrm{L})\end{array}$ & & $p>0.05 *$ & $\begin{array}{l}p<0.05^{*} \\
p<0.05 \AA\end{array}$ & $\begin{array}{l}p<0.05^{*} \\
p>0.05 \neq \\
p>0.05 \Omega\end{array}$ & $\begin{array}{l}p<0.05 * \\
p>0.05 \Phi \\
p<0.05 @\end{array}$ \\
\hline & $0.94 \pm 0.08$ & $0.99 \pm 0.18$ & $1.98 \pm 0.24$ & $1.33 \pm 0.42$ & $1.25 \pm 0.24$ \\
\hline Creatinine (mg/dl) & & $p>0.05 *$ & $\begin{array}{l}p<0.05^{*} \\
p<0.05 \AA\end{array}$ & $\begin{array}{l}p<0.05 * \\
p>0.05 \neq \\
p>0.05 \Omega\end{array}$ & $\begin{array}{l}p<0.05 * \\
p>0.05 \rrbracket \\
p<0.05 @\end{array}$ \\
\hline & $8.38 \pm 2.40$ & $8.53 \pm 2.3$ & $44.48 \pm 2.2$ & $20.48 \pm 3.1$ & $17.48 \pm 1.1$ \\
\hline $\begin{array}{l}\text { Blood urea nitrogen } \\
(\text { BUN) }(\mathrm{mg} / \mathrm{dl})\end{array}$ & & $p>0.05 *$ & $\begin{array}{l}p<0.05^{*} \\
p<0.05 \AA\end{array}$ & $\begin{array}{l}p<0.05^{*} \\
p>0.05 \neq \\
p>0.05 \Omega\end{array}$ & $\begin{array}{l}p<0.05 * \\
p>0.05 \llbracket \\
p<0.05 @\end{array}$ \\
\hline & $12.05 \pm 3.75$ & $11.05 \pm 2.75$ & $22.90 \pm 3.10 *$ & $17.20 \pm 4.11$ & $13.30 \pm 3.01$ \\
\hline $\begin{array}{l}\text { Serum uric acid } \\
(\mathrm{mg} / \mathrm{dl})\end{array}$ & & $p>0.05 *$ & $\begin{array}{l}p<0.05^{*} \\
p<0.05 \circledR\end{array}$ & $\begin{array}{l}p<0.05^{*} \\
p>0.05 \neq \\
p>0.05 \Omega\end{array}$ & $\begin{array}{l}p<0.05 * \\
p>0.059 \\
p<0.05 @\end{array}$ \\
\hline
\end{tabular}

$\mathrm{N}:$ Number of rats in each group $=10$.

@: Groups V were compared to group III.

* : All groups were compared to control group I.
(®): Groups III was compared to group II.

$\Omega$ : Groups IV was compared to group III.

II : Groups V was compared to group IV 
Table (3): Effects of Moringa oleifera seeds aqueous extract on oxidant and antioxidant renal homogenate levels in different groups (Mean $\pm \mathrm{SD})$.

\begin{tabular}{|c|c|c|c|c|c|}
\hline $\begin{array}{l}\text { Groups } \\
\text { Parameters }\end{array}$ & $\begin{array}{l}\text { Control } \\
\text { normal } \\
\text { (Group I) }\end{array}$ & $\begin{array}{l}\text { Moringa seeds aqueous } \\
\text { extract-treated group } \\
\text { (Group II) }\end{array}$ & $\begin{array}{l}\text { Diabetic } \\
\text { group } \\
\text { (Group III) }\end{array}$ & $\begin{array}{l}\text { Diabetic-Moringa seeds } \\
\text { aqueous extract } \\
\text { treated group } \\
\text { (Group IV) }\end{array}$ & $\begin{array}{c}\text { Diabetic -pretreated with } \\
\text { Moringa seeds aqueous } \\
\text { extract-treated group } \\
\text { (Group V) }\end{array}$ \\
\hline & $64.09 \pm 6.43$ & $59.05 \pm 4.33$ & $87.00 \pm 5.22$ & $59.06 \pm 1.23$ & $62.22 \pm 1.44$ \\
\hline $\begin{array}{l}\text { MDA level } \\
\text { (nmol/g wet } \\
\text { renal tissue) }\end{array}$ & & $p>0.05^{*}$ & $\begin{array}{l}p<0.05^{*} \\
p<0.05 \AA\end{array}$ & $\begin{array}{l}p<0.05^{*} \\
p>0.05 \neq \\
p>0.05 \Omega\end{array}$ & $\begin{array}{l}p<0.05^{*} \\
p>0.05 \text { I } \\
p<0.05 @\end{array}$ \\
\hline & $350.34 \pm 8.14$ & $360.14 \pm 5.32$ & $150.54 \pm 5.13$ & $267.11 \pm 2.10$ & $253.09 \pm 7.16$ \\
\hline $\begin{array}{l}\text { SOD level } \\
\text { (U/mg protein) }\end{array}$ & & $p>0.05^{*}$ & $\begin{array}{l}p<0.05^{*} \\
p<0.05 \AA\end{array}$ & $\begin{array}{l}p<0.05^{*} \\
p<0.05 \neq \\
p>0.05 \Omega\end{array}$ & $\begin{array}{l}p<0.05^{*} \\
p>0.05 \llbracket \\
p<0.05 @\end{array}$ \\
\hline
\end{tabular}

$\mathrm{N}:$ Number of rats in each group $=10$.

@: : Groups V were compared to group III.

* : All groups were compared to control group I.

histological structure of renal parenchyma and glomeruli (Figs. 1,2). In diabetic group, there was collapsed glomerular tuft with marked tubular atrophy associated with interstitial inflammation and interstitial hemorrhage (Fig. 3). Meanwhile, the kidney sections of diabetic rats in group IV

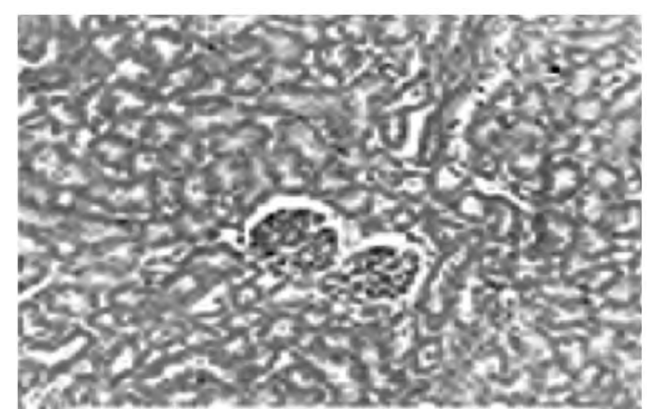

Fig. (1): Kidney of the normal control rats showed normal renal histological structure of renal parenchyma and glomeruli (Hx \& E, 400X).

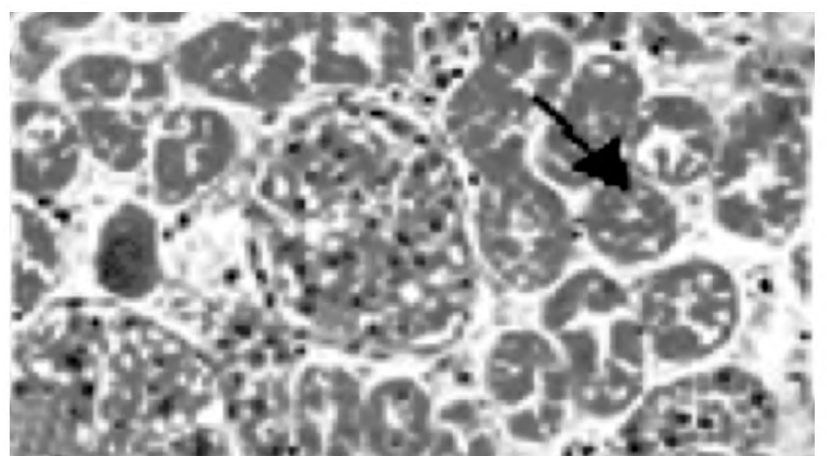

Fig. (3): Rats from the untreated diabetic group showed thickened glomerular basement membrane, vacuolated endothelial lining glomerular tuft, and vacuolated epithelial lining renal tubular cells (blacked arrow) (Hx \& E, 400X).
$\Omega$ : Groups IV was compared to group III.

(1): Groups III was compared to group II.

II : Groups V was compared to group IV

and $\mathrm{V}$ that treated with the Moringa seeds aqueous extract before and after induction of diabetes seemed to be restoring the normal appearance of glomeruli and regenerated tubules with interstitial hemorrhage, and the kidney nearly restored the normal cortical tissue (Figs. 4,5).

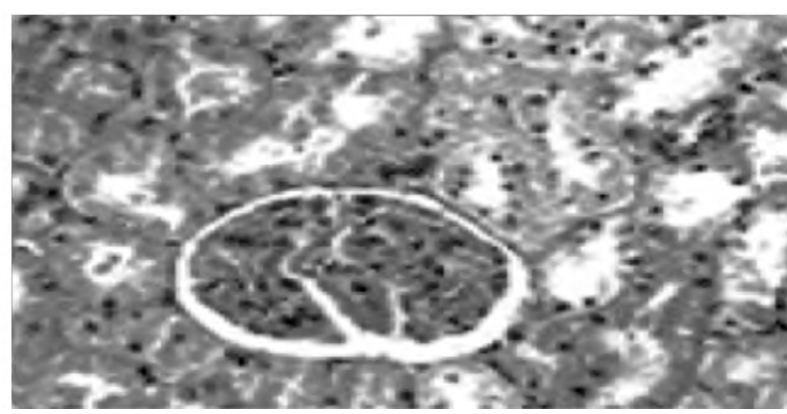

Fig. (2): Kidney of the normal control rats received Moringa seeds extract showed normal renal histological structure of renal parenchyma and glomeruli $(\mathrm{Hx} \& \mathrm{E}$, 400X).

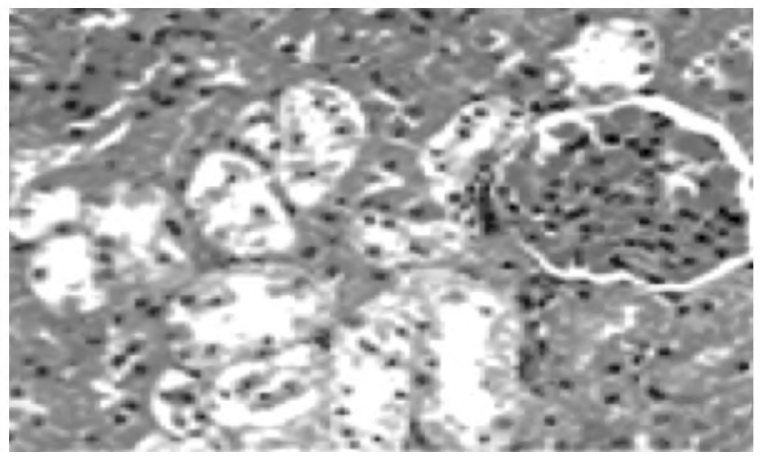

Fig. (4): Treating diabetic rats with Moringa seeds extract nearly restored the renal tissues to their normal histology with minimal histopathological changes (Hx \& E, 400X). 


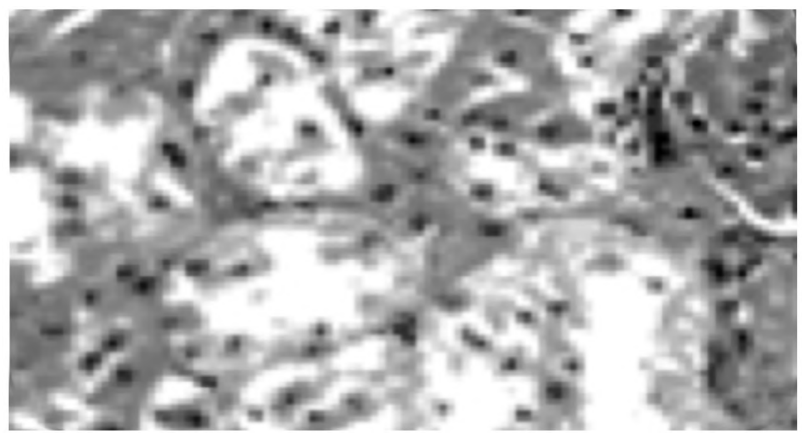

Fig. (5): Pretreated diabetic rats with Moringa seeds extract showed the renal tissues nearly normal with minimal histopathological changes (Hx \& E, 400).

\section{Discussion}

Results of the present study revealed that alloxan injection revealed a significant higher level of both serum glucose and HbA1C levels, and lower level of insulin when compared to control group. The toxic action of alloxan on pancreatic $\mathrm{P}$-cells is the summation of several processes such as generation of free radicals, inhibition of glucokinase, selective destruction of pancreatic insulin secreting P-cells [17] and DNA damage [18]. Such damaged DNA activates nuclear polysynthetase which depletes the cellular pool of oxidized NAD + resulting in 0 -cells damage and decreasing insulin level [19].

In the present study, treatment with Moringa seeds aqueous extract resulted in a significant reduction in fasting serum glucose (FSG) and $\mathrm{HbA1c}$, and significant elevation of insulin level in comparison with diabetic untreated group. These findings could be attributed to improved hepatic insulin sensitivity resulting in decreased hepatic glucose production [20].

Jeong and his Co-Workers [21] mentioned that Moringa may improve muscle insulin sensitivity resulting in increased tissue glucose uptake. These results were also in consistent with that obtained in a study performed by Alessandro et al., [22] who found a significant reduction in serum glucose and $\mathrm{HbA1c}$ levels with Moringa treatment of diabetic patients.

Olayaki and his Co-Workers [23] observed that oral administration of extract of Moringa significantly reduces serum glucose concentration and glycosylated-Hb in alloxan-induced diabetic rats. The possible mechanism by which Moringa oleifera brings its hypoglycemic action could be due to potentiating the insulin effect by increasing either the pancreatic secretion of insulin from cells of islets of Langerhans, Mozo et al., [24], or its release from the bound form [25].

These results were in disagreement with Rutchaporn et al., [26] where they found insignificant reduction in serum glucose and $\mathrm{HbA} 1 \mathrm{c}$ levels with Moringa treatment of diabetic patients. This could be due to the short duration of treatment (4 weeks). In this study, the anti-diabetic activity of the extract in pretreated group (group V) was significantly higher than the non-treated group with the extract before induction of diabetes. This suggested that the extract had a protective effect against diabetes mellitus.

This study also showed a significant increase in the serum levels of $\mathrm{Na}^{+}$and $\mathrm{K}+$ in the diabetic control group compared with the control groups.

Al-Malki and El-Rabey [27] observed that treating diabetic rats with Moringa seeds powder significantly ameliorates both sodium and potassium levels compared with those of the control group.

Elevation in serum glucose concentration increase plasma tonicity, creating an osmotic driving force that favors the movement of water from the intracellular space to the extracellular space, thereby diluting the extracellular concentration of sodium [28].

Treatment with aqueous extract of Moringa oleifera seeds significantly increased $\mathrm{Na}^{+}$concentration in all treated groups compared with the diabetic control group.

A significant elevation in serum creatinine and urea levels indicates an impaired renal function of diabetic animals [22]. An increase in creatinine, urea and uric acid levels occurred when there is damage to the kidney or when the kidney is not functioning properly. Increment of blood creatinine and urea levels with the increment of serum sugar level clearly indicates that the increase serum sugar level causes damage to the kidney [29] .

Rawoof and his Co-Workers [30] mentioned that values of urea, creatinine, and uric acid in the serum of the diabetic group significantly increased indicates a progressive renal damage.

Diabetic nephropathy is the renal disease that occurs as a result of diabetes. Therefore the decreased levels of creatinine and urea in the treated groups shows that treatment of the disease with aqueous extracts of Moringa oleifera seed can guard against diabetic nephropathy, Al-Malki and El-Rabey [27]. 
Nabila and her Co-workers [31] mentioned that treatment with Moringa was effective which was represented by a decrease of serum urea and creatinine. In accordance, many studies reported that serum urea and creatinine increase in diabetic rats due to diabetic nephropathy.

Diabetes is characterized by disturbances in nephron function, which leads to impaired renal excretion of hydrogen and potassium, and result in hyperkalemia and a hyperchloremic normal-gap acidosis [22].

The renal tissues of diabetic rats showed also the symptoms of diabetic nephropathy illustrated in the hypertrophy of both glomerular and tubular elements, and increase in the thickness of glomerular basement membranes [28]. The histopathological alterations in the alloxan-induced diabetes together, with the other tests, achieved to diagnose diabetes which emphasized that diabetic nephropathy was grown as one of the diabetic complications [32].

Treating diabetic rats with Moringa seeds extract restored the normal renal function and histology of kidney with no pathological changes and controlled diabetic nephropathy [27].

Treatment with aqueous extract of Moringa oleifera seeds significantly decreased the level of potassium ion in all treated groups compared with the diabetic control group.

Oxidant stress markers which are critical factors in the progression of diabetic nephropathy increases by inflammatory mechanisms of injury in the kidney. Among antioxidative enzymes, SOD which catalyzes dismutation of the superoxide anion into hydrogen peroxide [33]. Moringa oleifera has antioxidant activity because it contains three classes of phytochemicals which are glucomoringin, flavonoides (quercetin and kaempferol) and phenolic acids [34].

Normal rats treated with aqueous extract of Moringa oleifera seeds showed insignificant changes in the renal tissue levels of both MDA and SOD.

Prasanna and his-Co-Workers [35] mentioned that treatment with Moringa oleifera decreases lipid peroxidation. This may be attributed to the ability of Moringa oleifera to increase the excretion of fecal cholesterol and hypolipidemic effects.

In this work, the reduced activities of SOD in kidney of alloxan-diabetic rats elevated significantly.
Serino and Salazar [36] mentioned that the untreated diabetic rats on their work showed a significant increase in the renal MDA, and the activity of SOD significantly diminished in renal tissue homogenate in relation to control group. It could reflect oxidative pressure which might be a mirror to diminished antioxidant defense potential as hyperglycemia and hyperlipidemia are associated with decreasing defense system body in warding off free radical [37].

These findings agreed with Karina and his CoWorkers [3] who reported a significant augment in serum SOD, and a significant decrease of MDA on Moringa oleifera ingestion to diabetic patients. The enhanced accumulation of these free radicals and dysfunction of antioxidant defense system resulted in oxidative stress [38]. These radicals can bind covalently to the macromolecules, and induce peroxidative degradation of the membrane lipids rich in polyunsaturated fatty acids, leading to the formation of lipid peroxides followed by multiple pathological changes Czerska et al., [39]. Illana et al., [40] reported that diabetes mellitus enhanced the free radical generation in various ways. Several studies suggested that disorders of lipid metabolism, hyperlipidemia and obesity are associated with overproduction of oxygen free radicals [41]

Ghiridhari and his Co-Workers [42] mentioned that the administration of aqueous extract of Moringa oleifera seeds to diabetic rats for 10 weeks exhibited a significant amelioration of both MDA and SOD. SOD is a natural antioxidant produced by cells. The tissue SOD level is inversely proportional to plasma glucose.

Moringa oleifera has antioxidant activity because it contains three classes of phytochemicals which are glucomoringin, flavonoides (quercetin and kaempferol) and phenolic acids [43] .

Swathi et al., (2017) reported that there was a significant decrease in MDA level and marked increase in SOD activities in rat receiving aqueous extract of Moringa oleifera seeds.

\section{Conclusion:}

Moringa extracts played a significant role as potent hypoglycemic agents which were capable of improving other clinical conditions associated with diabetes mellitussuch as the kidney function. Moringa oleifera showed protective effect on blood glucose levels and kidney functions as well as lipid peroxidation. 


\section{Acknowledgement:}

The authors like to express deep gratitude to Dr/Gamal Abdel-Hamid, professor of General Pathology, Al-Azhar Faculty of Medicine,for his help and guidance in histopathologic part of the work.

\section{References}

1- ADEEYO A., ADEFULE D., OFUSORI D., ADERINOLA1 A., E.A. and CAXTON E.: Antihyperglycemic effects of aqueous leaf extract of mistletoe and moringa oleifera in streptozotocin-induced diabetes wistar rats. Diabetologia Croatica J., 42-53, 2013.

2- ALAM M., CHOWDHURY M., JAIN P. and SAGOR H.M.: DPP-4 inhibitor sitagliptin prevents inflammation and oxidative stress of heart and kidney in two kidney and one clip (2K1C) rats. Journal of Functional Food, 7 (64): 107-115, 2015.

3- ALESSANDRO L., SIMONA B., SARA D., ANGELA B., STEFANO R., GIGLIOLA B., FABIO F. and ALBERTO B.: Effect of Moringa oleifera Leaf Powder on Postprandial Blood Glucose Response: In Vivo Study on Saharawi People Living in Refugee Camps. Nutrients J., 10: 1494-1506, 2018.

4- AL-MALKI A.L. and El-RABEY H.A.: The antidiabetic effect of low doses of Moringa oleifera lam seeds on streptozotocin induced diabetes and diabetic nephropathy in male rats. Bio. Med. Res., 38: 1040-54, 2015.

5- ASARE A., GYAN B. and BUGYEI K.: Toxicological evaluation of the aqueous leaf extract ofMoringa oleifera Lam. (Moringaceae), Journal of Ethnopharmacology, 139: 330-336, 2012.

6- CZERSKA M., MIKOLAJEWSKA K., ZIELINSKI M., GROMADZINSKA J. and WASOWICZ W.: Today's oxidative stress markers. Med. Pr., 66 (3): 393-405, 2015.

7- EL-DESOUKI N.I., BASYONY M.A., HEGAZI M.M. and EL-AAMA M.S.I.: Moringa oleifera leaf extract ameliorates glucose, insulin and pancreatic beta cells disorder in alloxan-induced diabetic rats. Res. J. Pharm. Biol. Chem., 6 (3): 642-654, 2015.

8- ELIZABETH P., MILLS K., PAIGE D., BROWN J.D., SMITH P.W. and KATIE T.: Treating nonalcoholic fatty liver disease in patients with type 2 diabetes mellitus: A review of efficacy and safety. Therapeutic Advances in Endocrinology and Metabolism, 9 (1): 15 -28, 2017.

9- EZAZUL H., SUBBOROTO K.K., DIPA I. and REZUANUL I.: Comparative study between the effect of cocciniacordifolia (Leaf and Root) powder on hypoglycemic and hypolipidemic activity of alloxan-induced type II diabetes long-Evan rats. Journal of Diabetes and Endocrinology, 3 (4): 37-43, 2012.

10- FALOWO A.B., MUKUMBO F.E., IDAMOKORO E.M., LORENZO J.M., AEOLIAN A.J. and MUCHENJE V.: Multi-functional application of Moringa oleifera Lam. In nutrition and animal food products: Food Res. Int. J., 106: 317-334, 2018.

11- GHIRIDHARI A., MALHATI D. and GEETHA K. Antidiabetic properties of drumstick (Moringa oleifera) leaf tablets. International Journal of Health and Nutrition, 2: $1-5,2011$.
12- GOUDA M., MOUSTAFA A., HUSSEIN L. and HAMZA M.: Three week dietary intervention using apricots, pomegranate juice and/or fermented sour sobya and impact on biomarkers of anti-oxidative activity, oxidative stress and erythrocytic glutathione transferase activity among adults. Nutr. J., 15 (1): 52-61, 2016.

13- ILLANA L., ELIANE B. and JORGE M.: Pomegranate seed oil (PunicaGranatum L.): A Source of Punicic Acid (Conjugated a-Linolenic Acid. J. Hum. Nutr. Food Sci., 2 (1): 1024-35, 2014.

14- ISSAOUI M., FLAMINI G. and BRAHMI F.: Effect of the growing area conditions on differentiation between Chemlali and Chétoui olive oils. Food Chemistry, 119 (1): 220-225, 2010.

15- ITALO M., AZEVEDOI I., ARAUJO F., MARIANNY M., MARILIA D. and ALDO C.V.: Wound healing of diabetic rats treated with Moringa oleifera extract. Acta. Cir. Bras, 33 (9): 799-805, 2018.

16- JAJA C., GRAF B., SIMMLER C., KIM Y., KUHN P., PAULI G.F. and RASKIN I.: Biochemical characterization and anti-inflammatory properties of an isothiocyanateenriched moringa (Moringa oleifera) seed extract. PLOS ONE J., 12: 2658-69, 2017.

17- JEONG H.Y., SE H.M., CHANG H.A., YOUNG M.C. and SEOKYUNG H.: Comparison of non-insulin antidiabetic agents as an add-on drug to insulin therapy in type 2 diabetes: A network meta-analysis. Scientifics Reports, 8 (409): 5018-5043, 2018.

18- KANWAR Y., WADA J. and SUN A.: Diabetic nephropathy: Mechanisms of renal disease progression. Experimental Biology and Medicine, 233 (1): 4-11, 2018.

19- KARINA V., EDWIN G., RODRIGO E. and GONZÁLEZ R.: Effects of Moringa oleifera on glycaemia and Insulin Levels: A Review of Animal and Human Studies. Nutrients J., 11: 2907-14, 2019.

20- MARGONI A., PERREA D.N., VLACHOS I., PROKOPAKI G., PANTOPOULOU A., FOTIS L., KOSTAKI M. and PAPAVASSILIOU A.: Serum Leptin, Adiponectin and Tumor Necrosis Factor-a in Hyperlipidemic Rats with/without Concomitant Diabetes Mellitus. The Feinstein Institute for Medical Research, 17 (2): 36-40, 2011.

21- MICHAEL P.C.: Insulin action and resistance in obesity and type 2 diabetes. Nature Medicine Science, 23: 804814, 2017.

22- MOZO R., CAOLE A. and ANG I.: The Effects of Malunggay (Moringa oleifera) leaves capsule supplements on high specificity C-reactive protein and hemoglobin A1c levels of diabetic patients. J. Intern. Med., 53: 1-10, 2015.

23- NABILA I. EL-DESOUKI, MOHAMED A., MONA M. and MOHAMED S.: The antidiabetic effect of Moringa oleifera leaves extract on some biochemical parameters of diabetic rats induced alteration in cyto-skeletal desmin of cardiomyocytes. Research Journal of Pharmaceutical, Biological and Chemical Sciences, 8 (1): 1585-99, 2017.

24- NADEEM M. and IMRAN M.: Promising features of Moringa oleifera oil: Recent updates and perspectives. Lipid Health Dis. J., 15: 212-20, 2016.

25- OLAYAKI L., IREKPITA E. and YAKUBU T.: Methanolic extract of Moringa oleifera leaves improves glucose tolerance, glycogen synthesis and lipid metabolism in 
alloxan-induced diabetic rats. J. Basic Clin. Physiol. Pharmacol., 26 (6): 585-93, 2015.

26- OLSON A.L.: Regulation of GLUT4 and insulin-dependent glucose flux. ISRN Molecular Biology, 2012: 1-12, 2012.

27- PAPACCIO G., PISANTI F.A., LATRONICO M.V., AMMENDOLA E. and GALDIERI M.: Multiple lowdose and single high-dose treatments with streptozotocin do not generate nitric oxide. J. Cell Biochem., 77: 82-91, 2017.

28- PARVEEN R., AGARWAL N.B., KAUSHAL N., MALI G. and RAISUDDIN S.: Efficacy and safety of canagliflozin in type 2 diabetes mellitus: Systematic review of randomized controlled trials. Expert Opin. Pharmacother., 9: 1-11, 2019.

29- PRASANNA K., RAVI T. and MANDAPAKA A.: Effect of moringa oleifera on blood glucose, LDL levels in typesII diabetic obese people. Innovative Journal of Medical and Health Science, 3: 23-25, 2014.

30- RAHMA A., KUSHARTO A., DAMAYANTHI E. and ROHDIANA D.: Single and mixture administration of white tea (Camellia sinensis) and moringa (Moringa oleifera) as antihyperglycemic in diabetic male rats (Sprague-dawley) induced by streptozotocin. Earth and Environmental Science J., (1): 196-201, 2018.

31- RAN N., KAORI H. and HIROSHI I.: Effects of High Glucose and Lipotoxicity on Diabetic Podocytes. MDPI Nutrients J., (241): 1-11, 2021.

32- RAWOOF K., ANWAR M., FAYROUZ Y., MAYSOUN M. and SULTANA E.: Effect of moringa oleifera, Hordeumvulgare and their mixture on microvascular complications of diabetes mellitus. International Journal of Current Research, 10 (03): 67066-67068, 2018.

33- ROUHI S.Z., MOKLESUR R., ASMAH R., SAAD A. and FAUZIAH O.: The effect of pomegranate fresh juice versus pomegranate seed powder on metabolic indices, lipid profile, inflammatory biomarkers, and the histopathology of pancreatic islets of Langerhans in streptozotocin-nicotinamide induced type 2 diabetic SpragueDawley rats. Complementary and Alternative Medicine, 17: 156-69, 2017.

34- RUTCHAPORN T., NATCHAGORN L., SATHIT V., PRAVIT A. and APIRADEE S.: Effect of Moringa oleifera Leaf Capsules on Glycemic Control in Therapy-Native
Type 2 Diabetes Patients: A Randomized Placebo Controlled Study. Evidence-Based Complementary and Alternative Medicine, 6 (201): 1390-96, 2017.

35- SERINO A. and SALAZAR G.: Protective role of polyphenols against vascular inflammation, aging and cardiovascular disease, J. Functional Food, 11 (1): 103662-73, 2018.

36- SWATHI P., GANA K., MANJUSHA M. VIVEKAN A., RAMKISHAN A. and BHAVANI B.: Effect of Morus Alba against Hyperglycemic and Hyperlipidemic Activities in Streptozotocin Induced Diabetic Nephropathy. Biosciences Biotechnology Research Asia, 14 (4): 1441 1447, 2017.

37- TIWARI B.K., PANDEY K.B., ABIDI and A.B. and RIZVI S.I.: Markers of oxidative stress during diabetes mellitus. J. Biomarkers, 1-8, 2013.

38- TOMITA I., KUME S., SUGAHARA S., OSAWA N., YAMAHARA K., YASUDA-YAMAHARA M., TAKEDA N., CHIN-KANASAKI M., KANEKO T. and MAYOUX E.: SGLT2 Inhibition Mediates Protection from Diabetic Kidney Disease by Promoting Ketone Body-Induced mTORC1 Inhibition. Cell Metab., 32: 404-419, 2020.

39- UNE H.D., SHINGANE P. and PATAVE T.R.: Study on the effects of Moringa oleifera lam. Pod extract on alloxan induced diabetic rats. Asian Journal of Plant Science and Research, 4 (1): 36-41, 2014.

40- VILLARRUEL A., LOPEZ D.A., VAZQUEZ O.D., PUEBLA A.G., TORRES M., GUERRERO L. and NUNO K.: Effect of Moringa oleifera consumption on diabetic rats. BMC Complementary and Alternative Medicine, 18 (127): 2180-90, 2018.

41- WANG N., ZHANG P., XIAO Y.X., ZHAO Y., ZHANG B., XIN W. and WEN Y.: Associations between changes in glucagon-like peptide-1 and body weight reduction in patients receiving acarbose or metformin treatment. Journal of Diabetes, 9: 728-737, 2016.

42- WILLIAM E.G.: Models of Fixation and Tissue Processing. Biotech. Histochem, 84 (5): 185-193, 2010.

43- ZHANG L., YANG Y., ZU X., CHEN F., WANG Z. and LIU F.: Oxidative stability of sunflower oil supplemented with carnosic acid compared with synthetic antioxidants during accelerated storage. Food Chemistry, 118 (3): 656662,2010 


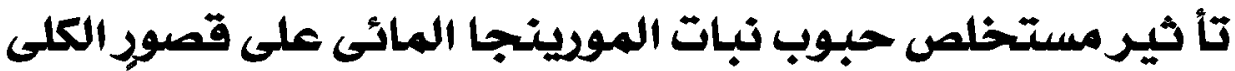

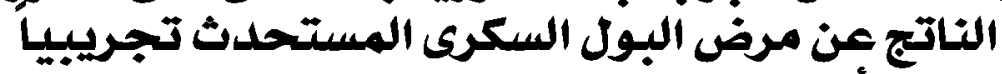

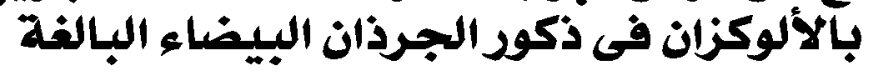

\footnotetext{
خلفية البحث: نبات المورينجا هو عشب يستخدم فى الطب التقليدى لخواصه العلاجية. الهدف من البحث: تقييم تأثير مستخلص حبوب المورينجا المائى على ذكود الجرذان البيضاء المصابة بمرض السكر على وظائف الكلى. طرق ومواد البحث: أجريت هذه الدراسة فى قسم الفسيولوجيا الطبية بكلية الأزهر بالقاهرة، بدأت الدراسة فى شهر سبتمبر وانتهت فى في إنى

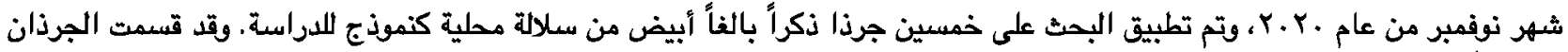

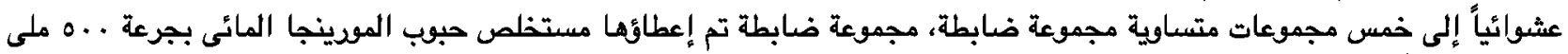

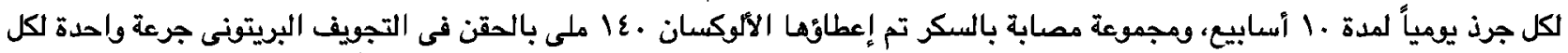

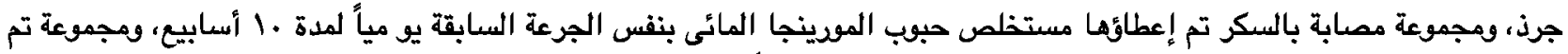

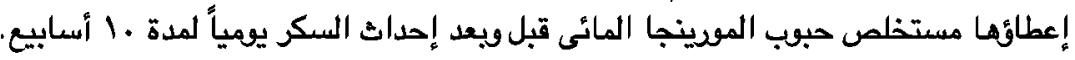

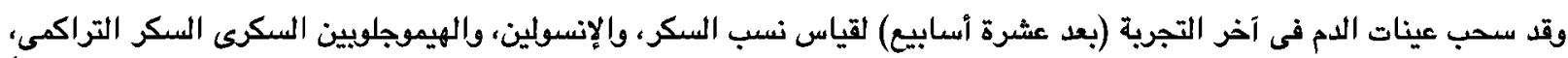

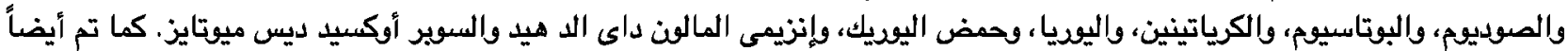

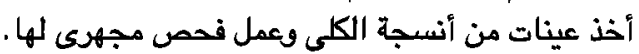

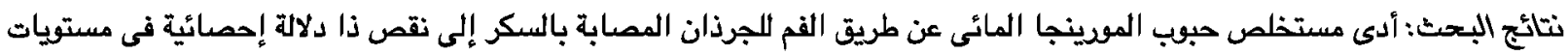

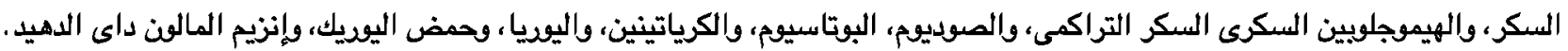

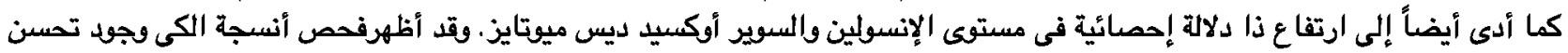

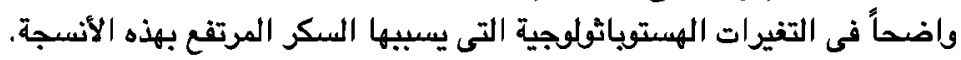

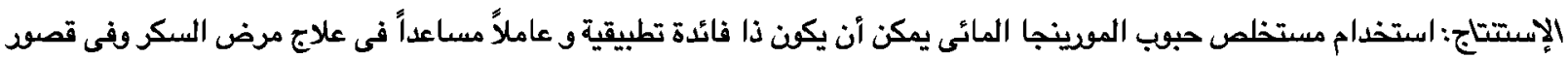

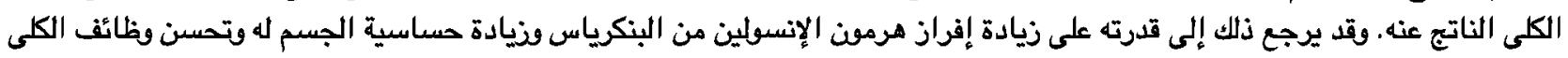

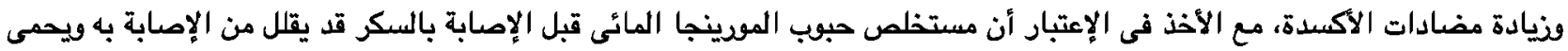

